\title{
Subtropical grasses in Bay of Plenty dairy pastures
}

\author{
CC. BELL' and B. KEENE ${ }^{2}$ \\ 1 AgResearch Grasslands, Private Bag 11008, Pamerston North \\ 2 Bay Milk Products Ltd, Private Bag I, Edgecumbe
}

\begin{abstract}
Data collected for Bay Milk Products Ltd, using a standard rate of growth technique, were analysed to assess the effects of $\mathrm{C}_{4}$ grasses on total pasture and ryegrass growth rates. In the years when $C_{4}$ grasses were prominent summer growth rates were at their maximum but there was no evidence that ryegrass growth rates were penalised by the $C_{4}$ grass component in the same or subsequent years. The results show that $\mathrm{C}_{4}$ grasses are widespread in the BOP and will continue to be an important part of the BOP dairy pasture ecosystem. Several suggestions are made on how to reduce the $C_{4}$ grass component of the pastures, but it should be recognised that agronomically useful types could form a useful component of the sward in years when climatic conditions during the summer period are conducive to their vigorous growth.
\end{abstract}

Keywords: $\mathrm{C}_{4}$ grasses, pasture growth, subtropical grasses, summer production

\section{Introduction}

$\mathrm{C}_{4}$ grasses have been an important part of BOP pastures for several decades. Paspalum dilatatum (paspalum) was cited as being as far south as Hawke's Bay and Taranaki in 1936, (Hamblyn 1936) and was an important source of feed in the BOP district in the early 1950s (Levy 1951; Allo,1953). Paspalum, ryegrass and white clover mixed pastures were considered the ideal for the coastal BOP in the 1960s (Al10 \& Hewitt 1961). Other $\mathrm{C}_{4}$ grasses had assumed sufficient prominence to be regarded as serious weeds in the late 1950s, e.g., Cynodon dactylon and Paspalum distichum, Sporobolus africanus with annual grasses such as Digitaria sanguinalis and Echinochloa crus-galli sufficiently prolific to ruin some crops ( Bantield 1955; Allo 1959).

Recently there has been increased interest in $C_{4}$ grasses and their potential spread owing to the possible increase in temperatures brought about by global warming. It has been suggested ryegrass is already losing ground to $\mathrm{C}_{4}$ grasses in BOP dairy pastures (Moloney 1990). There is a paucity of information on the annual fluctuations of $\mathrm{C}_{4}$ grasses in the pastures of the BOP; however, one data set from Bay Milk Products Ltd does have limited information on the presence of the dominant "other grass" species in Lolium perenne-based dairy pastures. Patterns of pasture growth and species composition have been monitored on several BOP dairy farms since the winter of 1989; the first 2 years' results for initial sites have been published by Baars et al. (199 1) (Note that the weeds and other grass figures are transposed in their publication.) This paper covers the extended data set and concentrates on the $C_{4}$ grass component of the pastures.

\section{Methods}

Pasture growth was measured by cutting at monthly intervals using cages to exclude grazing in a similar manner to the "standard rate of growth technique" used by Radcliffe (1974). Pasture measurements were undertaken by Pasture Assessment Ltd, Whangarei for Bay Milk Products Ltd. Over the period of July 1989 to May 1995, a total of nine farms were monitored, each farm having one to three cage sites. Cage sites were sited so as to represent major soil or pasture differences within the farm. The farms in the monitoring group were changed about every 3 years. The farms were sited at Papamoa, Pongakawa, Maketu, with two farms at Opotiki, Galatea, and Edgecumbe. Herbage samples were separated into ryegrass, other grasses, clover, weeds, and dead material, with the major component of the "other grass" portion identified. In general $\mathrm{C}_{4}$ grass species were present in sufficient quantity in January-February-March to be listed as the dominant grass in the "other grass" component of the dissection samples and so results for the "other grass" component provide a good indication of the $\mathrm{C}_{4}$ component of the sward over the summer period. $\mathrm{C}_{4}$ grasses that were listed as dominant at some period were Digitaria sanguinalis (summer grass), paspalum, Setaria sp., Echinochloa crus-galli (barnyard grass), and Panicum dichotomiflorum (smooth witchgrass). Seasonal pattern and component yield results presented are averages of all cage sites and for brevity only rate of growth results are presented. Component rates of growth were calculated as the product of total sward growth rates and percentage botanical composition. 


\section{Results}

The highest pasture growth rates were recorded in the first two years of the monitoring programme, although summer pasture production was very variable with, for example, February growth rates ranging between 25 and $80 \mathrm{~kg} \mathrm{DM} / \mathrm{ha} /$ day (Figure I). $\mathrm{C}_{4}$ grasses were present at all nine sites. Within each year the highest yield of "other grasses" was generally recorded in February (Figure 2) and in the first summer of the monitoring scheme February yields reached a maximum of $50 \mathrm{~kg} \mathrm{DM} / \mathrm{ha} /$ day but declined over the following three summers to reach a minimum of $4 \mathrm{~kg} \mathrm{DM} / \mathrm{ha} /$ day in 1993. Ryegrass growth rates were less variable than those of the "other grasses" (February growth rates 8-29 kg DM/ ha/day) and there was no evidence of a consistent summer growth pattern (Figure 3). In the first year (1989-90) the percentage of ryegrass declined from July to February but recovered by the following July (Figure 4). Over the six years the average ryegrass percentage in January has varied from 23 to $50 \%$ and for February from 15 to $42 \%$ while the average other grass percentage in January has varied from 9 to $23 \%$ and for February from 15 to $63 \%$.

\section{Discussion}

Although $\mathrm{C}_{4}$ grasses were not individually separated within the "other grass" component they were consistently identified as the dominant species and so the results presented here confirm that $\mathrm{C}_{4}$ grasses are present throughout the $\mathrm{BOP}$ and indicate that in some summers they can make a significant contribution to pasture production. These species have been present for several decades in the BOP and because (a) they can be readily introduced to new sites by seed spread via the grazing animal, on equipment used for cultivation, in water courses, and transported in late hay crops and (b) some seeds persist for many years ( $>10$ years) in the seed-bank (Burnside et al. 198 1), $\mathrm{C}_{\mathbf{4}}$ species are likely to become increasingly common as the seed-bank levels increase and new sites are colonised. Under certain climatic conditions, e.g., hot moist summers (Pearcy \& Ehleringer 1984) they have the potential to become an important component of pastures, and this may be assisted by specific management practices. Matthews (1971) suggests that certain cropping practices (e.g., repeated cropping of paddocks), over-grazing, insect attack and herbicide use all assist the establishment of $\mathrm{C}_{4}$ grasses through provision of sites for colonisation Thus normal year-to-year climate variability and local management practices are just as likely to be determining the presence of $\mathrm{C}_{4}$ grasses as the small increase in mean
Figure 1 Seasonal distribution of pasture growth rate averaged for nine Bay of Plenty dairy farms.

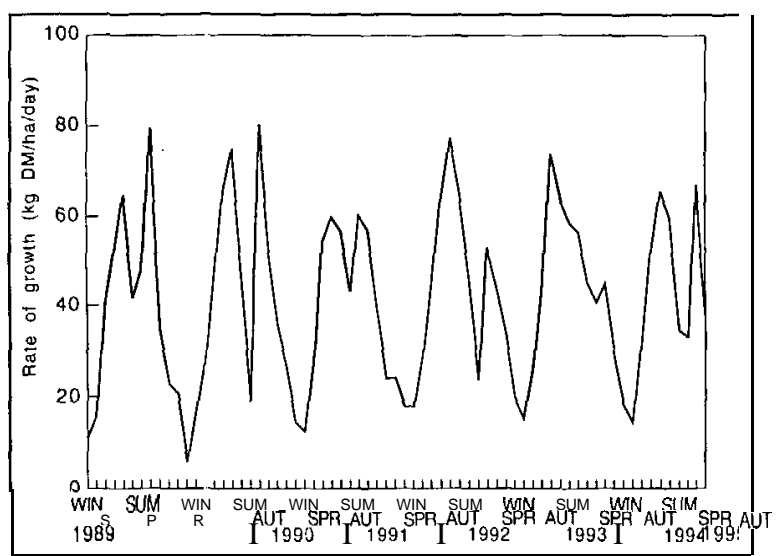

Figure 2 The rate of growth of grasses other than ryegrass (principally $\mathrm{C}_{\mathbf{4}}$ grasses) on nine Bay of Plenty dairy farms.

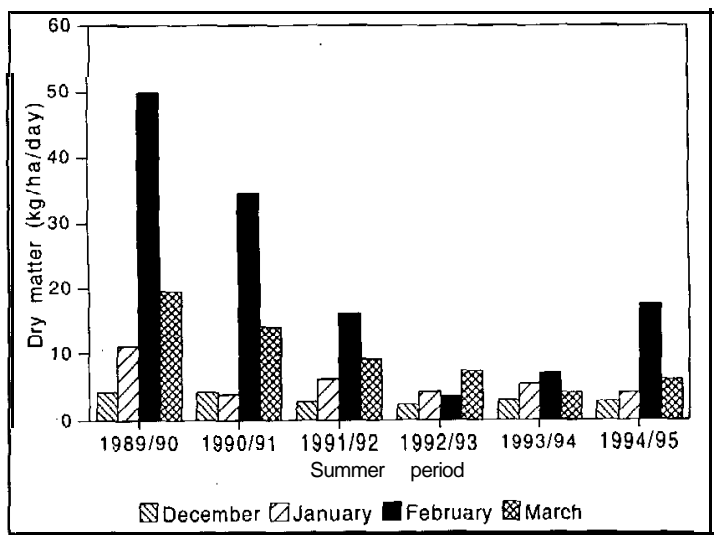

temperature recorded over the past decades in New Zealand (Salinger et al. 1993).

The results do not suggest that $\mathrm{C}_{4}$ grasses are suppressing ryegrass, as ryegrass growth rates were relatively consistent between years and in general varied independently of the "other grass" component. This was evident in the second year when ryegrass and "other grass" growth rates were both high in February-March. In the worst "other grass" years, e.g., the summer of 1989-90, the peak of "other grass" growth was in February but the decline in ryegrass growth rates and percentage ryegrass started prior to this (Figures 3 and 4). This suggests that the "other grasses", of which $\mathrm{C}_{4}$ species are the dominant component in the summer, are not suppressing ryegrass but are opportunistic components of the pasture that can substantially 
Figure 3 The rate of growth of ryegrass on nine Bay of Plenty dairy farms

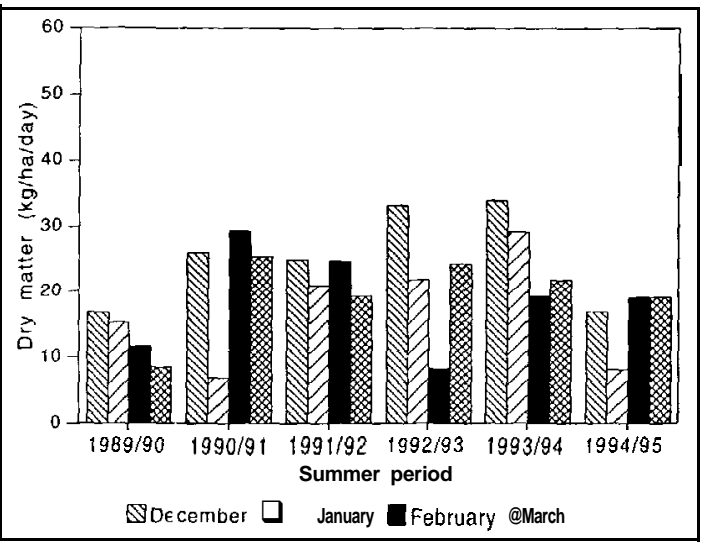

Figure 4 The average ryegrass percentage for the four farms monitored in the first year (1989-90).

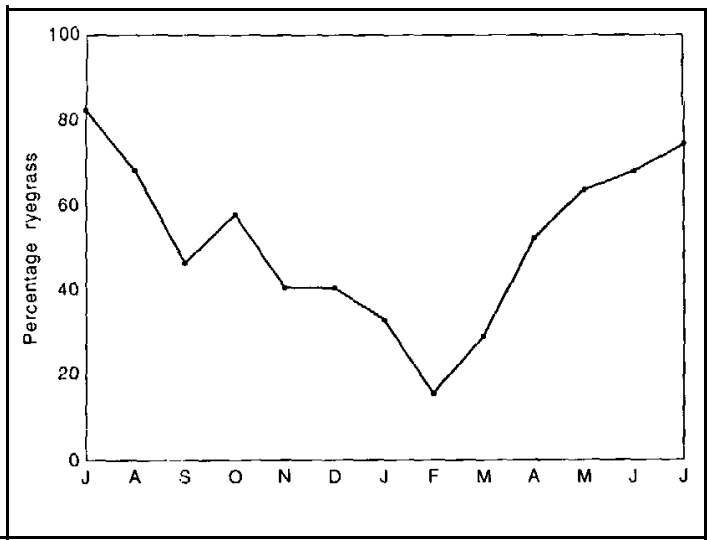

contribute to yield in some years. The importance of this contribution is demonstrated by the fact that the highest summer growth rates were recorded in years when the growth of "other grasses" was also high. In the absence of $\mathrm{C}_{4}$ grass species, other opportunistic weed species (Lambert $e t$ al. 1977), not "desirable" $C_{3}$ species, would probably increase in these years.

These results also highlight the temporal problems associated with monitoring the spread of $\mathrm{C}_{\mathbf{4}}$ grasses, as their contribution to yield depends upon seasonal conditions and therefore displays high within and between year variability. These results show that, for the BOP, herbage assessments for $\mathrm{C}_{\mathbf{4}}$ grasses are best undertaken in February-March and, to obtain a reliable assessment of their contribution to pasture yields, have to be repeated over several years. The only recent survey of botanical composition of New Zealand pastures conducted in the late spring-early summer of 1987-88 listed only one dominant $C_{4}$ grass association out of 115 sampling sites for the central region of the North Island of New Zealand (Field 1989); had this survey been conducted later in the summer, or over several years, the results would probably have demonstrated a larger and more variable presence of $\mathrm{C}_{4}$ grasses.

If it is perceived as desirable to reduce the $\mathrm{C}_{4}$ grass component of pastures, it must be remembered for annual $\mathrm{C}_{4}$ grasses that prevention of seeding is critical. The old gardening adage "one year's seeding is ten years weeding" is applicable to $\mathrm{C}_{4}$ grass invasion. Some practical management strategies to prevent seeding could include:

* Maintaining spring-summer pasture cover on paddocks containing $\mathrm{C}_{4}$ grasses thus increasing the competition for emerging shoots or seedlings

* Concentrating grazing on infested paddocks in the late summer to prevent seed set.

* Using selective herbicides and oversowing affected areas with other grass species.

* Not cropping paddocks that have become infested with $\mathrm{C}_{4}$ grasses or, if they are cropped, using broadleaf crops so that grass-selective herbicides can be used against the $C_{4}$ species.

* Using alternative species to compete with $\mathrm{C}_{4}$ grasses and provide mid- to late-summer production.

Perhaps the fundamental question posed by this paper is: are $\mathrm{C}_{4}$ grasses a weed whose control is essential if sward productivity is to be maintained or could they be a useful sward component that can sometimes make a significant contribution to yield? If the former is mostly likely, then control will be best achieved where the ecology of the $\mathrm{C}_{4}$ species is well understood and the information used to design suitable strategies to accomplish botanical change that will reduce the $\mathrm{C}_{4}$ species. Whatever the answer, further research is necessary to quantify the effects the presence of $C_{4}$ grasses have on milk production not just pasture growth rates.

\section{ACKNOWLEDGEMENTS}

Drs Harry Clark and Paul Newton for helpful comments on this manuscript.

\section{REFERENCES}

Allo, A.V. 1953. Paspalum and its place in the Bay of Plenty. Proceedings of the New Zealand Grassland Association 1.5: 90-94. 
Allo, A.V. 1959. Weed problems of the Bay of Plenty. Proceedings of the New Zealand Weed Control Conference 12: 17-23.

Allo, A.V.; Hewitt, S.R. 1961. Farming in the Bay of Plenty. Proceedings of the New Zealand Grassland Association 23: 24-3 1.

Banfield, G.L. 1955. Weed control in drains. Proceedings of the New Zealand Weed Control Conference 8: 77-80.

Baars, J.A.; Goold, G.J.; Hawke, M.F.; Kilgarriff, P.J.; Rollo, M.D. 1991. Seasonal patterns of pasture production in the Bay of Plenty and Waikato. Proceedings of the New Zealand Grassland Association 53: 67-72.

Burnside, O.C.; Fenster, C.R.; Evetts, L.L.; Mumm, R.F. 198 1. Germination of exhumed weed seed in Nebraska. Weed science 29: 577-586.

Field, T.R.O. 1989. Vegetational survey of management pastures in New Zealand. Proceedings of the International Grassland Congress XVI: 1407-1408.

Franklin, S.J. 1980. Weed control in Asparagus. Proceedings of seminar on Asparagus: 37-47, Advisory Services Division, MAF, Hamilton.
Hamblyn, C.J. 1936. Paspalum as a pasture-grass. Proceedings of the New Zealand Grassland Association 5: 59-66.

Lambert, J.P. 1977. Comparison ofryegrass and kikuyu grass pastures under mowing. New Zealandjournal of experimental agriculture 5: 71-77.

Levy, E.B. 1951. Grasslands of New Zealand. Wellington: Government Printer.

Matthews, L.J. 1971. Warm-zone annual grasses. Proceedings of the New Zealand Weed and Pest Control Conference 24: 85-89.

Moloney, S. 1990. 'Huge change' in pastures; ryegrass losing battle. Dairy Exporter, August: 22.

Pearcy R.W.; Ehleringer, J. 1984. Comparative ecophysiology of $\mathrm{C}_{3}$ and $\mathrm{C}_{4}$ plants. Plant cell and environment 7: 1-13.

Radcliffe, J.E. 1974. Seasonal distribution of pasture production in New Zealand. I. Methods of measurement. New Zealandjournal of experimental agriculture 2: 337-340.

Salinger, M.J.; Hay, J.; McGann, R.; Fitzharris, B. 1993.

Southwest Pacific temperatures: diurnal and seasonal trends. Geophysical research letters 20 No. 10: 935 938. 